\title{
In vivo effect of endothelin-1 on plasma calcium and parathyroid hormone concentrations
}

\author{
J-M Chang, S-J Hwang, J-C Tsai and Y-H Lai \\ Division of Nephrology, Department of Medicine, Kaohsiung Medical University, Kaohsiung 807, Taiwan \\ (Requests for offprints should be addressed to Y-H Lai, Division of Nephrology, Department of Medicine, Affiliated Hospital, Kaohsiung Medical University, \\ 100 Shih-Chuan 1st Road, Kaohsiung 807, Taiwan; Email: jemich@cc.kmu.edu.tw)
}

\begin{abstract}
We have previously reported an in vitro inhibitory effect of endothelin-1 (ET-1) on parathyroid hormone (PTH) secretion. In the present experiment, ET-1 was infused into rabbits to study the in vivo effect of ET-1 on the changes in calcium, magnesium, PTH and calcitonin concentrations. Femoral arteries and veins of anesthetized male rabbits were cannulated to monitor vital signs, blood sampling and infusion of the agents being studied. Infusion of ET-1 (1, 5, 10 and $20 \mathrm{ng} / \mathrm{kg}$ per min) induced a dose-dependent decline in plasma ionized calcium concentrations from $6.68 \pm 0.26$ to $5 \cdot 50 \pm 0.46 \mathrm{mg} / \mathrm{dl}$ $(P<0.05)$ and a decrease in calcitonin concentrations from $48 \cdot 6 \pm 6 \cdot 5$ to $32 \cdot 5 \pm 4 \cdot 7 \mathrm{pg} / \mathrm{ml}$. PTH concentrations increased from $58 \cdot 3 \pm 10 \cdot 2$ to $159 \cdot 4 \pm 22 \cdot 1 \mathrm{pg} / \mathrm{ml}$. In a separate experiment, calcium gluconate solution was simultaneously infused to keep calcium concentrations steady, thereby proving a calcium 'clamp'. In normal calcium concentration, ET-1 infusion gradually decreased PTH concentrations from $71 \cdot 4 \pm 8 \cdot 6$ to $38 \cdot 0 \pm 6 \cdot 2 \mathrm{pg} / \mathrm{ml}$. We
\end{abstract}

further infused sodium citrate solution to decrease the calcium concentration $(2.0 \mathrm{mg} / \mathrm{dl}$ less $)$ and calcium gluconate solution was infused to keep calcium concentrations steadily less than normal. PTH concentrations were initially stimulated by the induction of hypocalcemia $(68 \cdot 1 \pm 11 \cdot 2$ to $135 \cdot 6 \pm 8 \cdot 5 \mathrm{pg} / \mathrm{ml})$, but decreased by ET-1 infusion ( $135 \cdot 6 \pm 8 \cdot 5$ to $85 \cdot 1 \pm 15 \cdot 2 \mathrm{pg} / \mathrm{ml})$. Plasma magnesium concentrations did not change significantly throughout the entire study and calcitonin concentrations were not significantly changed during the calcium clamp studies. Serum phosphate and $1,25-(\mathrm{OH})_{2}$ vitamin $\mathrm{D}_{3}$ concentrations were also measured, but they also did not change significantly. In conclusion, ET-1 exhibited an in vivo acute hypocalcemic action, independent of calcitonin. It also directly decreased PTH secretion if serum calcium concentrations were kept steady. The above findings are consistent with the results of our previous in vitro experiment.

Journal of Endocrinology (2000) 165, 179-184

\section{Introduction}

Endothelin-1 (ET-1) is widely distributed in various tissues and displays multiple biological activities (Masaki 1993). In bovine species, parathyroid glands expressed strong ET-1 message, only slightly less than that in the lungs (Fujii et al. 1991). Further, it has been suggested that ET-1 could inhibit parathyroid hormone (PTH) secretion from bovine parathyroid cells (Eguchi et al. 1992). Work in our laboratory has recently proved that ET-1 inhibited PTH secretion through an increase in intracellular calcium concentrations, and might act as a counter-regulatory factor for PTH secretion in the low-calcium state (Chang et al. 1997). However, the in vivo action of ET-1 on parathyroid function was not defined, although the above in vitro studies suggest an inhibitory role. It has been reported that the PTH concentrations in some patients decrease during thyroid operations, and this suggested that locally released ET-1 might be responsible (Nomura et al.
1994). These investigators further infused ET-1 to rats and stated that ET-1 might have an in vivo inhibitory effect on PTH secretion. However, the ET-1 dosage used was pharmacological, and the calcemic status was not monitored in their study. The present study was designed to clarify the in vivo effect of ET-1 on PTH secretion, with special attention to the calcemic status throughout the study.

\section{Materials and Methods}

\section{Animals}

Male New Zealand White (NZW) rabbits (body weight $2 \cdot 0-2 \cdot 5 \mathrm{~kg}$ ) were anesthetized by i.m. injection of $50 \mathrm{mg} /$ $\mathrm{kg}$ pentobarbital. Bilateral femoral arteries and veins were cannulated with polyethylene tubing (PE-50) filled with $10 \%$ heparin solution. One arterial cannula was connected to a pulsed doppler Hemodynamic Analysis System (Gould 
Inc., Valley View, OH, USA) for continuous monitoring of blood pressure and heart rate. Another arterial cannula was used to draw blood samples. The venous cannulae were connected to separate infusion pumps for infusion of ET-1, sodium citrate or calcium gluconate solution. Blood samples $(1.5 \mathrm{ml})$ were obtained through one of the arterial cannulae before and every $20 \mathrm{~min}$ throughout every experiment for the purpose of making various measurements. The same volume of $0.9 \%$ saline was given after each blood sampling to keep the animal euvolemic.

\section{ET-1 infusion}

After baseline blood sampling, animals were given ET-1 (human, Sigma) through the venous cannula: $1 \mathrm{ng} / \mathrm{kg}$ per min for $1 \mathrm{~h}$, followed by infusion of 5,10 and $20 \mathrm{ng} / \mathrm{kg}$ per min for $1 \mathrm{~h}$ each dose. In the same period of infusion, equal amounts of normal saline were given.

\section{ET-1 infusion under steady normocalcemia or hypocalcemia (calcium 'clamp')}

The effect of ET-1 on PTH secretion remains obscure, although it is known that infusion of ET-1 lowers calcium concentrations and consequently stimulates PTH secretion. Attempts were made to clarify this issue by keeping serum calcium concentrations steady with concomitant infusion of calcium gluconate during ET-1 treatment, giving $1 \mathrm{ng} / \mathrm{kg}$ per min ET-1 for $1 \mathrm{~h}$, followed by 5,10 and $20 \mathrm{ng} / \mathrm{kg}$ per min for $1 \mathrm{~h}$ each dose. During this normocalcemic clamp experiment, infusion of ET-1 solution in the same dosage served as control. In another experiment, acid citrate-dextrose (ACD) and calcium gluconate solutions were given to keep serum calcium concentrations at a steady $2 \mathrm{mg} / \mathrm{dl}$ less than baseline. Rates of infusion of ACD and calcium gluconate were titrated to achieve stable plasma calcium concentrations for at least two additional measurements. ET-1 infusion was then begun via the other infusion pump, the dosages of ET-1 being 1, 5, 10 and $20 \mathrm{ng} / \mathrm{kg}$ per min, $1 \mathrm{~h}$ for each dose. In this hypocalcemic clamp experiment, infusion of ACDcalcium gluconate solution was performed as control. In these two clamp studies, blood samples were drawn every 10 min for the measurement of calcium, calcitonin and PTH concentrations. Phosphate, magnesium and 1,25$(\mathrm{OH})_{2}$ vitamin $\mathrm{D}_{3}$ were also measured every $20 \mathrm{~min}$.

Assay for ionized calcium, phosphate, magnesium, ET-1, calcitonin, 1,25- $(\mathrm{OH})_{2}$ vitamin $\mathrm{D}_{3}$, and intact $\mathrm{PTH}(1-84)$

Plasma concentrations of ionized calcium were measured immediately using a $\mathrm{Ca}^{2+} / \mathrm{pH}$ Analyzer (Ciba-Corning, USA). Serum inorganic phosphate and magnesium concentrations were measured with spectrophotometry. To measure hormones, $1.5 \mathrm{ml}$ blood was drawn into prechilled polystyrene tubes containing $100 \mathrm{KIU}$ aprotinin, and immediately centrifuged. ET-1 was determined with a high sensitivity RIA kit (Amersham, Amersham, Bucks, UK). The cross-reaction was 7\% for ET-2 and 35\% for big ET-1. PTH concentrations were measured by IRMA kit (Nicholes Institute, San Juan Capistrano, CA, USA) for intact PTH(1-84). 1,25-(OH $)_{2}$ vitamin $\mathrm{D}_{3}$ was measured with a radioreceptor assay (Incstar Corp., Stillwater, MN, USA). Calcitonin assay was performed using an RIA kit using rabbit antiserum (Peninsula Laboratories, Belmont, CA, USA).

\section{Statistical analysis}

Significance of the differences between data from the experimental and control groups was analyzed by Student's $t$-test. The difference was taken as significant if the $P$ value was less $0 \cdot 05$.

\section{Results}

\section{Monitoring the vital signs}

Major hemodynamic factors - blood pressure and heart rate - were monitored throughout the entire study. Mean arterial pressure and heart rate did not change significantly during the infusion of ET-1, ACD solution and calcium, although an increase in systolic blood pressure by $10-$ $15 \mathrm{mmHg}$ was observed in two animals when the maximal dosage of ET-1 was given.

\section{Reliability of PTH measurements}

The baseline plasma ionized calcium concentration was $6 \cdot 20 \pm 0.48 \mathrm{mg} / \mathrm{dl}$ and the intact PTH concentration was $62 \cdot 4 \pm 10 \cdot 4 \mathrm{pg} / \mathrm{ml}$. ACD and calcium gluconate solutions were used to change serum calcium concentrations. As shown in Fig. 1, the PTH concentration increased (mean values) from 62.4 to $130 \cdot 2 \mathrm{pg} / \mathrm{ml}(209 \%)$ when the calcium concentration was decreased from 6.24 to $4.56 \mathrm{mg} / \mathrm{dl}$ by infusion of ACD solution. PTH concentrations decreased progressively to $23 \cdot 2 \%$ of baseline (mean value from 62.4 to $14.6 \mathrm{pg} / \mathrm{ml}$ ) when the calcium concentration was increased from 6.24 to $7.56 \mathrm{mg} / \mathrm{dl}$ by infusion of calcium gluconate. These results suggested that this IRMA PTH assay was suitable for use in this study to determine the rabbit PTH concentrations, because it reliably reflected the inverse calcium-PTH relationship, as expected.

\section{Plasma ET-1 concentrations during ET-1 infusion}

Plasma concentrations of ET-1 during its infusion are shown in Fig. 2. Before the start of infusion, plasma ET-1 concentrations of the animals receiving and those not receiving infusion were comparable: $3 \cdot 1 \pm 0 \cdot 6$ and 




Figure 1 Changes in PTH concentrations under various calcemic challenges. This experiment was done to test the reliability of the IRMA PTH assay for use in rabbits. The PTH IRMA assay kit effectively reflected the changes in PTH secretion in various calcemic conditions. Each line and symbol represent the changes in PTH concentrations in one animal. The arrow indicates the mean of the basal ionized calcium concentration, $6 \cdot 20 \pm 0.48 \mathrm{mg} / \mathrm{dl}$.

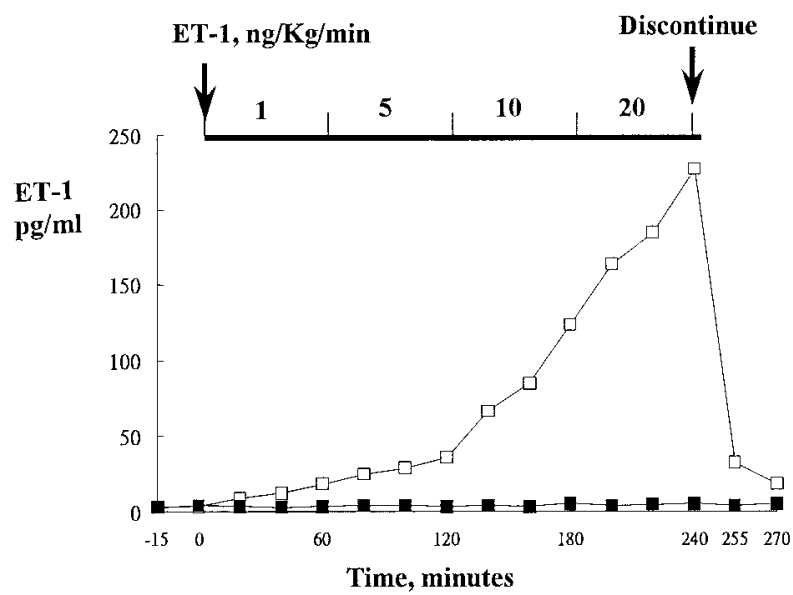

Figure 2 Plasma ET-1 concentrations before, during and after infusion of various doses of ET- $1(n=4, \square)$ or saline $(n=4$,

$3 \cdot 0 \pm 0 \cdot 2 \mathrm{pg} / \mathrm{ml}$ respectively. Plasma ET-1 concentrations did not change obviously throughout the experiment period among those animals not given ET-1. ET-1 infusion resulted in a gradual but marked increase in the plasma ET-1 concentration as the dosage of ET-1 was gradually increased: $12 \cdot 6 \pm 2 \cdot 1 \mathrm{pg} / \mathrm{ml}$ after $1 \mathrm{ng} / \mathrm{kg}$ per min ET-1 infusion, $28 \cdot 6 \pm 2 \cdot 3 \mathrm{pg} / \mathrm{ml}$ after $5 \mathrm{ng} / \mathrm{kg}$ per $\mathrm{min}, 84.5 \pm 6.4 \mathrm{pg} / \mathrm{ml}$ after $10 \mathrm{ng} / \mathrm{kg}$ per $\mathrm{min}$ and $227 \cdot 8 \pm 19 \cdot 8 \mathrm{pg} / \mathrm{ml}$ after $20 \mathrm{ng} / \mathrm{kg}$ per min (the duration of the infusion of each dose was $60 \mathrm{~min}$ ). After ET-1 had been discontinued for $30 \mathrm{~min}$, plasma ET-1 concentrations decreased rapidly to $9 \cdot 3 \pm 1 \cdot 5 \mathrm{pg} / \mathrm{ml}$.


Figure 3 Changes in ionized calcium, calcitonin and PTH concentrations produced by infusion of ET-1 ( $\square$ ). ET-1 exerted an acute hypocalcemic effect that was dose dependent. Calcitonin concentrations were also decreased by high doses of ET-1. In response to hypocalcemia, PTH concentrations increased. Data are expressed as mean \pm S.D. $(n=4)$. ${ }^{\star} P<0 \cdot 05$ compared with control ( $\boldsymbol{\square}$, saline infusion).

Changes in calcium, phosphate, magnesium, PTH, $1,25-(\mathrm{OH})_{2}$ vitamin $\mathrm{D}_{3}$ and calcitonin concentrations during ET-1 infusion

Figure 3 shows the changes in calcium, PTH and calcitonin concentrations during the infusion of ET-1. We found a gradual decline in serum calcium concentration that was dose-responsive to gradual increases in ET-1 dosages: $6.68 \pm 0.26 \mathrm{mg} / \mathrm{dl}$ at baseline, $6.40 \pm 0.32 \mathrm{mg} / \mathrm{dl}$ at the end of infusion of $1 \mathrm{ng} / \mathrm{kg}$ per min, $5 \cdot 90 \pm$ $0.30 \mathrm{mg} / \mathrm{dl}$ at the end of $5 \mathrm{ng} / \mathrm{kg}$ per $\mathrm{min}, 5 \cdot 72 \pm$ $0.30 \mathrm{mg} / \mathrm{dl}$ at the end of $10 \mathrm{ng} / \mathrm{kg}$ per min and $5 \cdot 52 \pm 0 \cdot 20 \mathrm{mg} / \mathrm{dl}$ at the end of $20 \mathrm{ng} / \mathrm{kg}$ per min infusion. At the same time, there was a significant increase in PTH concentrations that was also dose-responsive to gradual increases in ET-1 dosage: $58 \cdot 3 \pm 10 \cdot 2 \mathrm{pg} / \mathrm{ml}$ at baseline, $71.5 \pm 14.4 \mathrm{pg} / \mathrm{ml}$ at the end of infusion of $1 \mathrm{ng} / \mathrm{kg}$ per min, $115 \cdot 7 \pm 20 \cdot 8 \mathrm{pg} / \mathrm{ml}$ at the end of $5 \mathrm{ng} / \mathrm{kg}$ per $\min , 137 \cdot 6 \pm 12 \cdot 7 \mathrm{pg} / \mathrm{ml}$ at the end of $10 \mathrm{ng} / \mathrm{kg}$ per min and $159 \cdot 4 \pm 22 \cdot 2 \mathrm{pg} / \mathrm{ml}$ at the end of $20 \mathrm{ng} / \mathrm{kg}$ per min infusion. During the infusion of ET-1 and development of hypocalcemia, calcitonin concentrations did not change significantly with the infusion of lower doses of ET-1: $48.6 \pm 6.5 \mathrm{pg} / \mathrm{ml}$ at baseline, $43 \cdot 7 \pm 7 \cdot 7 \mathrm{pg} / \mathrm{ml}$ with infusion of $1 \mathrm{ng} / \mathrm{kg}$ per min and 




Figure 4 Changes in PTH and calcitonin concentrations produced by infusion of ET-1 during normacalcemic clamp. In the experimental animals $(\square)$, serum calcium concentrations were kept steady by titration of calcium gluconate solution. In the control group ( $\mathbf{\square})$, ET-1 infusion was performed without simultaneous calcium gluconate titration. PTH concentrations gradually decreased during ET-1 infusion. Data are expressed as mean \pm S.D. $(n=4) .{ }^{*} P<0 \cdot 05$ compared with controls.

$46 \cdot 3 \pm 5 \cdot 8 \mathrm{pg} / \mathrm{ml}$ with $5 \mathrm{ng} / \mathrm{kg}$ per min. However, with the infusions of increased doses of ET-1, there was a dose-dependent decrease in calcitonin concentrations: $38 \cdot 8 \pm 4 \cdot 2 \mathrm{pg} / \mathrm{ml}$ at $10 \mathrm{ng} / \mathrm{kg}$ per min and $32 \cdot 5 \pm 4 \cdot 7 \mathrm{pg} /$ $\mathrm{ml}$ at $20 \mathrm{ng} / \mathrm{kg}$ per min ET-1 infusion. 1,25-(OH $)_{2}$ vitamin $\mathrm{D}_{3}$, phosphate and magnesium concentrations were not changed significantly throughout the infusion (data not shown).

\section{Effect of ET-1 on PTH and calcitonin concentrations during normocalcemic clamp}

In a separate experiment, calcium gluconate infusion was given along with ET-1, and the rate was titrated to achieve steady serum calcium concentrations. As shown in Fig. 4, PTH concentrations decreased with the gradual increase of the ET-1 dose if the calcium concentrations were kept steady. The PTH concentration at baseline was $71 \cdot 4 \pm 8 \cdot 6 \mathrm{pg} / \mathrm{ml}$; it reached $74.6 \pm 10 \cdot 1 \mathrm{pg} / \mathrm{ml}$ at the end of infusion of ET-1 $1 \mathrm{ng} / \mathrm{kg}$ per min, $60 \cdot 4 \pm 4 \cdot 9 \mathrm{pg} / \mathrm{ml}$ at the end of $5 \mathrm{ng} / \mathrm{kg}$ per $\min , 51 \cdot 7 \pm 7.7 \mathrm{pg} / \mathrm{ml}$ at the end of $10 \mathrm{ng} / \mathrm{kg}$ per min and $38.4 \pm 6 \cdot 2 \mathrm{pg} / \mathrm{ml}$ at the end of $20 \mathrm{ng} / \mathrm{kg}$ per min ET-1. High-dose ET-1 infusion induced a decrease in calcitonin concentrations, but the differences were not statistically significant.

\section{Effect of ET-1 on PTH concentrations during hypocalcemic clamp}

Hypocalcemia to about $2 \mathrm{mg} / \mathrm{dl}$ less than baseline $(6.25 \pm 0.42$ to $4.36 \pm 0.20 \mathrm{mg} / \mathrm{dl})$ was achieved by infusion of ACD solution; this calcium value was then kept steady by titration with the simultaneous use of ACD and calcium gluconate solutions throughout the entire experiment. PTH concentrations increased in response to hypocalcemia $(68 \cdot 1 \pm 10 \cdot 2$ to $125 \cdot 6 \pm 17 \cdot 4 \mathrm{pg} / \mathrm{ml})$ induced by ACD solution. After the initiation of ET-1 infusion, the hypocalcemia-stimulated PTH secretion was attenuated (Fig. 5) by high-dose ET-1 infusion. This demonstrated that ET-1 exerted a direct inhibitory effect on PTH secretion, independent of the calcemic status.

\section{Discussion}

The regulation of PTH secretion involves several mediators, including extracellular calcium (Brown 1991), magnesium (Mayer \& Hurst 1978), vitamin D (Cantley et al. 1985) and, most recently, ET-1 (Eguchi et al. 1992, Chang et al. 1997). Parathyroid cells were reported to express the second most abundant ET-1 message in bovine species, and these cells secreted ET-1 into the culture medium (Fujii et al. 1991). Data from our laboratory revealed that ET-1 secretion from bovine parathyroid cells responded to changes in extracellular calcium concentration, and that exogenous ET-1 was able to inhibit PTH secretion through increasing the intracellular calcium concentration (Chang et al. 1997). The in vivo effect of ET-1 on PTH secretion was first observed by Nomura et al. (1994), who infused ET-1 via rat carotid artery and found that ET-1 could decrease PTH concentrations. However, the calcium concentration was not measured simultaneously and no dose-response relationship could be found. The present in vivo experiment was designed to study the effect of various concentrations of ET-1 on PTH secretion, while carefully monitoring changes in plasma calcium concentrations. In this way, we aimed to clarify the calcium-ET-1-PTH interrelationship and the true systemic effect of ET-1 on PTH secretion.

The amino acid sequence of PTH varies among species. That of rabbit PTH is clearly different from that of human $\mathrm{PTH}$, but the cross-reactivity of the assay system between these two species was not stated by the manufacturer. To test the effectiveness of the human PTH assay system that we used with rabbit $\mathrm{PTH}$, we made the rabbit 


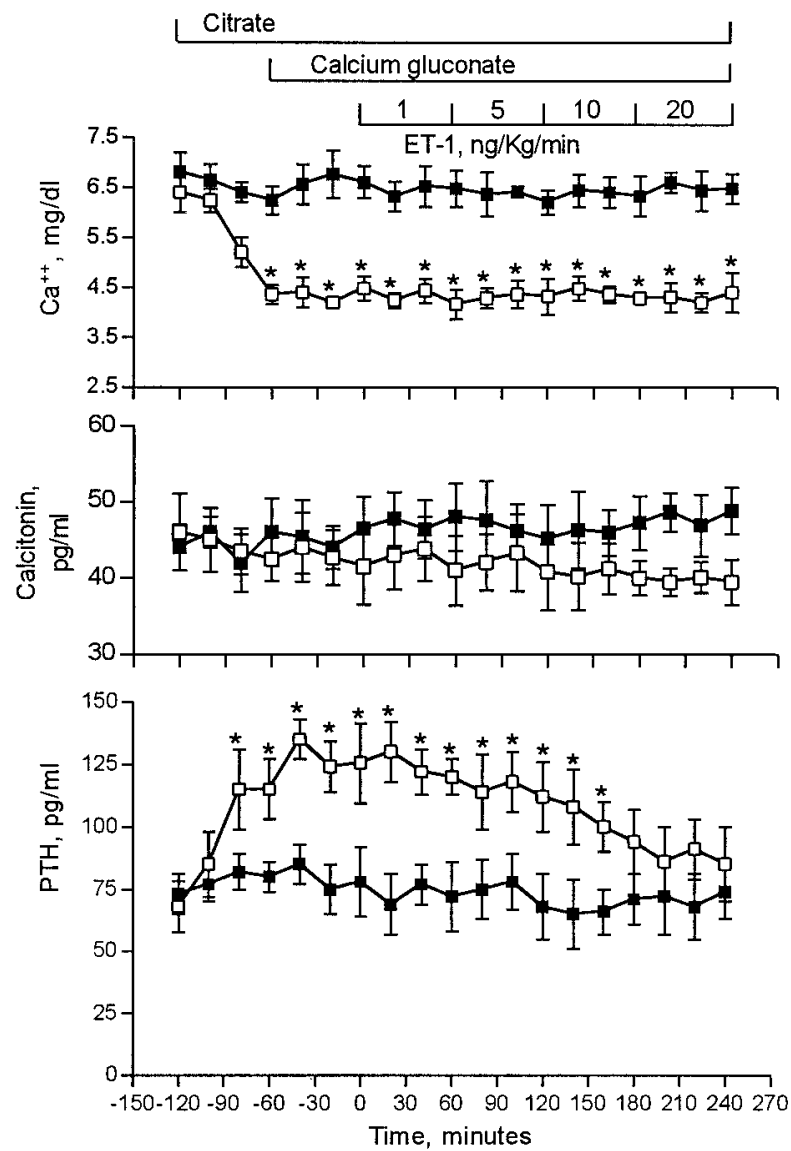

Figure 5 Effect of ET-1 on PTH secretion during the hypocalcemic clamp. Serum calcium concentrations were decreased by ACD solution, and maintained steady by titration with simultaneous infusion of calcium gluconate solution. ET-1 dose-dependently decreased the PTH concentrations stimulated by hypocalcemia. Control animals ( $)$ were given ACD-calcium gluconate infusion, but not ET-1, to maintain a steady calcium concentration. Data are expressed as mean \pm S.D. $(n=4)$. ${ }^{*} P<0 \cdot 05$ compared with controls. $\square$, Hypocalcemic clamp study group.

hypocalcemic and then hypercalcemic and measured the concomitant PTH concentration. Our results (Fig. 1) showed the reliability of this IRMA kit for use in the determination of rabbit PTH concentrations because the results obtained clearly reflected the inverse relation between calcium and PTH secretion.

In vitro studies of the effect of ET-1 on PTH secretion have produced inconsistent conclusions (Eguchi et al. 1992, Fujii et al. 1995, Chang et al. 1997), but the differences might be ascribed to different study designs and conditions. There have been several papers reporting the effect of infusion of ET-1 to either animals (Miller et al. 1989) or human volunteers (Vierhapper et al. 1990, Sorensen et al. 1994, Rabelink et al. 1994). However, the most frequently observed parameters were either systemic or organ-specific, such as changes in blood pressure, cardiac output, renal blood flow, glomerular filtration rate and various endocrine hormones. The influence of ET-1 on calcemic status and PTH secretion, however, has not been reported. In our study, we found that infusion of ET-1 progressively decreased the plasma calcium concentrations (Fig. 3) and that this action was dose-related. Plasma intact PTH concentrations, reflecting immediate secretion from parathyroid glands, increased in accordance with the decrease in plasma calcium. Therefore, ET-1 exerted an acute hypocalcemic effect that has not been reported in the literature. This unique calcium-lowering effect was independent of changes in the concentration of calcitonin, the only hormone known to exert such hypocalcemic action (Wisneski et al. 1978). In fact, ET-1 infusion was even shown to decrease the calcitonin concentrations in our study, although the decrease was not statistically significant.

The issue that most concerned us - a possible direct effect of ET-1 on PTH secretion - remains unanswered. The results shown in Figs 4 and 5 were obtained in the hope of clarifying this problem, as plasma calcium concentrations - the major regulator of PTH secretion - were kept stable in these experiments. We clearly demonstrated that ET-1 itself could suppress PTH secretion in a dose-dependent manner, whether calcium concentrations were normal or lower than normal. This is consistent with our previous in vitro experimental finding (Chang et al. 1997) that ET-1 was an inhibitory regulator of PTH secretion. It is not clear at present whether the PTH gene responds to ET-1, and this needs further study.

The mechanism underlying the basis of the hypocalcemic effect of ET-1 deserves further research. We have measured the concentrations of $1,25-(\mathrm{OH})_{2}$ vitamin $\mathrm{D}_{3}$ during the infusion of ET-1 and found that there was no significant change. Serum phosphate and magnesium concentrations were also unaltered. Therefore, the most probable site at which ET-1 acts to exert such a rapid hypocalcemic action is in the bone. The close proximity of osteoblasts to the vascular endothelial cells exposes them to endothelial cell products such as ET-1. ET-1 may stimulate osteoblasts to take up the calcium from plasma rapidly and acutely decrease the blood calcium concentration. There have been reports suggesting that endothelial cells greatly enhance the bone-forming function of osteoblasts (Villanueva \& Nimni 1990, Suzuki et al. 1997). Other in vitro studies also support the theory that ET-1 enhances the osteoanabolic effect in a concerted action with vitamin D (Kasperk et al. 1997). This concept is, however, still controversial because there are contradictory data (Hiruma et al. 1998). However, our results support the role of ET-1 in enhancing an osteoanabolic effect in the absence of vasoconstriction.

In summary, systemic infusion of ET-1 exerted an acutely hypocalcemic action, and directly suppressed PTH secretion regardless of the calcemic status. Simultaneous changes in $1,25-(\mathrm{OH})_{2}$ vitamin $\mathrm{D}_{3}$ and calcitonin 
concentrations were not observed. Further studies are needed to define the actual site of such an effect of ET-1.

\section{References}

Brown EM 1991 Extracellular $\mathrm{Ca}^{++}$sensing, regulation of parathyroid cell function, and role of $\mathrm{Ca}^{++}$and other ions as extracellular (first) messengers. Pharmacology Review 71 371-404.

Cantley LK, Russell J, Lettiei D \& Sherwood LM 1985 1,25Dihydroxy-vitamin D3 suppresses parathyroid hormone secretion from bovine parathyroid cells in tissue culture. Endocrinology 117 2114-2119.

Chang JM, Lai YH \& Tsai JH 1997 Interaction between extracellular calcium and endothelin-1 influences parathyroid hormone secretion from bovine parathyroid cells through the increase of intracellular calcium. Mineral and Electrolyte Metabolism 23 113-120.

Eguchi S, Hirata Y, Imai T, Kanno K, Akiba T, Sakamoto A, Yanagisawa M \& Masaki T 1992 Endothelin receptors in human parathyroid gland. Biochemical and Biophysical Research Communications 184 1448-1455.

Fujii Y, Moreira JE, Orlando C, Maggi M, Aurbach GD, Brandi ML \& Sakaguchi K 1991 Endothelin as an autocrine factor in the regulation of parathyroid cells. Proceedings of the National Academy of Sciences of the USA $\mathbf{8 8}$ 4235-4239.

Fujii Y, Tomic M, Stojilkovic SS, Iida T, Brandi ML, Ogino Y \& Sakaguchi K 1995 Effect of endothelin-1 on $\mathrm{Ca}^{++}$signaling and secretion in parathyroid cells. Journal of Bone and Mineral Research $\mathbf{1 0}$ $716-725$.

Hiruma Y, Inoue A, Shiohama A, Otsuka E, Hirose S, Yamaguchi A \& Hagiwara H 1998 Endothelins inhibit the mineralization of osteoblastic MC3T3-E1 cells through the A-type endothelial receptor. American Journal of Physiology 275 R1099-R1105.

Kasperk CH, Borcsok I, Schairer HU, Nawroth PP, Niethard FU \& Ziegler R 1997 Endothelin-1 is a potent regulator of human bone cell metabolism in vitro. Calcified Tissue International 60 368-374.
Masaki T 1993 Endothelins: homeostatic and compensatory actions in the circulatory and endocrine systems. Endocrine Reviews $\mathbf{1 4}$ 256-268.

Mayer GP \& Hurst JG 1978 Comparison of the effects of calcium and magnesium on parathyroid hormone secretion rate in calves. Endocrinology 102 1803-1807.

Miller WL, Redfield MM \& Burnett JC Jr 1989 Integrated cardiac, renal, and endocrine actions of endothelin. Journal of Clinical Investigation 83 317-320.

Nomura K, Yamashita J \& Ogama M 1994 Endothelin-1 is involved in the transient hypoparathyroidism seen in patients undergoing thyroid surgery. Journal of Endocrinology 143 343-351.

Rabelink TJ, Kaasjager KAH, Boer P, Stroes EG, Braam B \& Koomans HA 1994 Effects of endothelin-1 on renal function in humans: implications for physiology and pathophysiology. Kidney International 46 376-381.

Sorensen SS, Madsen JK \& Pedersen EB 1994 Systemic and renal effect of intravenous infusion of endothelin- 1 in healthy human volunteers. American Journal of Physiology 266 F411-F418.

Suzuki A, Shinoda J, Watanabe-Tomita Y, Ozaki N, Oiso Y \& Kozawa O 1997 ETA receptor mediates the signaling of endothelin-1 in osteoblast-like cells. Bone 21 143-146.

Vierhapper H, Wagner O, Nowotny P \& Waldhausl W 1990 Effect of endothelin-1 in man. Circulation 81 1415-1418.

Villanueva JE \& Nimni ME 1990 Promotion of calvarial cell osteogenesis by endothelial cells. Journal of Bone and Mineral Metabolism 5 733-739.

Wisneski LA, Croom WP, Silva OL \& Becker KL 1978 Salmon calcitonin in hypercalcemia. Clinical Pharmacology and Therapentics 24 219-222.

Received 7 June 1999

Revised manuscript received 20 December 1999 Accepted 20 January 2000 